\title{
JEDNOLITY SĄD PATENTOWY - Z PERSPEKTYWY POLSKI
}

\section{WPROWADZENIE}

Jednolity Sąd Patentowy ma zostać utworzony na podstawie umowy międzynarodowej zawartej przez państwa członkowskie Unii Europejskiej po dokonaniu ratyfikacji tej umowy przez co najmniej 13 państw, w tym Francję, RFN i Wielką Brytanię. Wspomniana umowa (porozumienie w sprawie Jednolitego Sąu Patentowego) ${ }^{1}$ stanowi składnik tzw. pakietu patentowego, majacego utworzyć jednolitą ochronę patentowa w państwach członkowskich Unii Europejskiej uczestniczących we wzmocnionej współpracy w tej dziedzinie. Obok porozumienia JSP w skład „pakietu patentowego” wchodzą dwa unijne akty prawne przyjęte 17 grudnia 2012 r., tj. rozporządzenie Parlamentu Europejskiego i Rady nr 1257/2012 wprowadzające wzmocnioną współpracę w dziedzinie tworzenia jednolitego systemu ochrony patentowej ${ }^{2}$ oraz rozporządzenie Rady nr 1260/2012 wprowadzające wzmocnioną współpracę w dziedzinie tworzenia jednolitego systemu ochrony patentowej w odniesieniu do majacych zastosowanie ustaleń dotyczących tłumaczeńn ${ }^{3}$.

Jednolita ochrona patentowa, której tytułem prawnym ma być patent europejski o jednolitym skutku, została scharakteryzowana w artykule opublikowanym w poprzednim zeszycie niniejszego czasopisma ${ }^{4}$. Celem poniższej analizy jest przedstawienie niektórych problemów wynikających na tle porozumienia JSP, w tym zwłaszcza zastrzeżeń co do jego zgodności z Konstytucja Rzeczypospolitej Polskiej.

Porozumienie JSP składa się z preambuły obejmującej 15 punktów i 89 artykułów ujętych w pięciu częściach, podzielonych na rozdziały. Jego integralną częścią jest statut JSP (załącznik I, składający się z 38 artykułów), a załącznik II określa podział spraw w oddziale centralnym (zob. niżej). Część I omawianej umowy, zawierająca postanowienia ogólne i instytucjonalne, składa się z siedmiu rozdziałów. W rozdziale I (postanowienia ogólne) tworzy się JSP i określa definicje, zakres stosowania, osobowość prawną i odpowiedzialność

\footnotetext{
${ }^{1}$ Tekst porozumienia JSP został opublikowany w dziale „Informacje” w Dz. Urz. UE C 175 z 20 czerwca 2013 r., s. 1 i n. (dalej jako: porozumienie JSP).

${ }^{2}$ Dz. Urz. UE L 361 z 31 grudnia 2012 r., s. 1 i n. (dalej jako: rozporządzenie nr 1257/12).

${ }^{3}$ Dz. Urz. UE L 361 z 31 grudnia 2012 r., s. 89 i n. (dalej jako: rozporządzenie nr 1260/12).

${ }^{4}$ Zob. A. Nowicka, Patent europejski o jednolitym skutku - konstrukcja prawna i treść, „Ruch Prawniczy, Ekonomiczny i Socjologiczny" 2013, z. 4, s. 19 i n.
} 
umowną i pozaumowną JSP. Rozdział II (postanowienia instytucjonalne) normuje strukturę JSP, w ramach której funkcjonować mają sąd pierwszej instancji, sąd apelacyjny, sekretariat oraz komitety (administracyjny, budżetowy i doradczy). Rozdział III (sędziowie JSP) określa kryteria uprawniające do mianowania na stanowisko sędziego, procedurę mianowania, niezawisłość i bezstronność sędziowska, zespół sędziów i ramowy program szkoleń. Rozdział IV (pierwszeństwo prawa Unii, odpowiedzialność prawna i obowiązki umawiających się państw członkowskich) statuuje pierwszeństwo prawa Unii i jego poszanowanie oraz reguluje wnioski o orzeczenia w trybie prejudycjalnym, odpowiedzialność umawiających się państw członkowskich za szkody spowodowane naruszeniem prawa Unii oraz odpowiedzialność tych państw opartą na art. 258-260 TfUE. Rozdział V (źródła prawa i prawo materialne) normuje źródła prawa stosowanego przez JSP oraz treść uprawnień wynikających zarówno z patentu europejskiego o jednolitym skutku, jak i „klasycznego” patentu europejskiego (prawo zakazania bezpośredniego i pośredniego korzystania z wynalazku, ograniczenia skutków patentu, prawo oparte na uprzednim stosowaniu wynalazku), wyczerpanie praw przyznanych na mocy patentu europejskiego oraz skutki dodatkowych świadectw ochronnych. Rozdział VI (jurysdykcja międzynarodowa i właściwość) normuje jurysdykcję międzynarodowa, właściwość JSP, właściwość oddziałów sądu pierwszej instancji oraz terytorialne skutki orzeczeń. Rozdział VII (mediacja i arbitraż) zawiera przepis tworzacy Centrum mediacji i arbitrażu w odniesieniu do patentów.

Część II obejmuje postanowienia finansowe, w tym dotyczące budżetu JSP i jego finansowania, a także finansowania ramowego programu szkoleń dla sędziów oraz Centrum mediacji i arbitrażu.

Część III reguluje organizację JSP i zawiera przepisy proceduralne. W rozdziale I (postanowienia ogólne) zawarto przepisy o statucie i regulaminie wewnętrznym JSP, a ponadto uregulowano zasadę proporcjonalności i sprawiedliwości, zarządzanie sprawami, procedury elektroniczne, postępowanie jawne, zdolność prawna, strony i ich zastępstwo. Przepisy rozdziału II (język postępowania) regulują język postępowania przed sądem pierwszej instancji i przed sądem apelacyjnym oraz zawierają pozostałe ustalenia dotyczace języka. Rozdział III (postępowanie przed JSP) reguluje procedury pisemna, dodatkową i ustna, środki dowodowe, ciężar dowodu i jego odwrócenie. Rozdział IV (uprawnienia JSP) określa ogólne uprawnienia oraz zawiera przepisy dotyczące biegłych sądowych, ochrony informacji niejawnych, nakazu przedstawienia i zabezpieczenia dowodów oraz przeszukania pomieszczeń, postanowień o zabezpieczeniu, środków tymczasowych i zabezpieczających, nakazów stałych, środków naprawczych w postępowaniu o naruszenie, orzeczeń w sprawie ważności patentu, uprawnień JSP dotyczących decyzji Europejskiego Urzędu Patentowego, nakazu przekazania informacji, przyznania odszkodowania, kosztów i opłat sądowych, pomocy prawnej oraz terminu przedawnienia. Rozdział V normuje odwołanie i jego skutki, orzeczenia w sprawie odwołania i przekazania sprawy do ponownego rozpoznania. W rozdziale VI uregulowano orzeczenia, określono ich podstawę i prawo do wysłuchania, a ponadto wymagania formalne, orzeczenia i zdania odrębne, ugodę, publikację orzeczeń, ponowne wysłuchanie oraz wykonanie orzeczeń i nakazów. 
Część IV zawiera postanowienia przejściowe, a w części V znajdują się postanowienia końcowe regulujące podpisanie, ratyfikację i przystapienie, funkcje depozytariusza, okres obowiązywania, rewizję, języki porozumienia i jego wejście w życie.

Jednolity Sąd Patentowy ma posiadać wyłączną jurysdykcję w niemal wszystkich sprawach dotyczących zarówno patentów europejskich o jednolitym skutku, jak i „klasycznych” patentów europejskich ${ }^{5}$, a ponadto w sprawach dotyczących dodatkowych świadectw ochronnych (SPC) ${ }^{6}$, w szczególności w sprawach o naruszenie i unieważnienie tych praw. Będzie to m.in. oznaczać, że sprawy o unieważnienie „klasycznych” patentów europejskich przestana należeć do wyłącznej jurysdykcji organów krajowych, co obecnie gwarantuje unijne rozporządzenie $\mathrm{nr}$ 44/20017. Również w odniesieniu do przyszłych patentów europejskich o jednolitym skutku porozumienie JSP doprowadzi do kolejnego, nader poważnego, gdyż dotyczącego sprawowania wymiaru sprawiedliwości na własnym terytorium, ograniczenia kompetencji państw członkowskich na rzecz JSP. Już w tym miejscu wskazać trzeba, że na gruncie Konstytucji powstaje zasadnicze pytanie o dopuszczalność przekazania władzy sądowniczej w tych sprawach.

Porozumienie JSP zostało otwarte do podpisu 19 lutego 2013 r. i tego dnia zostało podpisane przez 24 państwa członkowskie, a 5 marca 2013 r. przez Bułgarię. Podpisu nie złożyły Polska i Hiszpania (oraz Chorwacja, która przystapiła do Unii Europejskiej 1 lipca 2013 r.). Dotychczas ratyfikacji dokonały Austria i Malta.

Jak stanowi art. 89 ust. 1 porozumienia JSP, wejdzie ono w życie 1 stycznia 2014 r. (co przestało być realne) albo pierwszego dnia czwartego miesiaca po złożeniu trzynastego dokumentu ratyfikacji, albo pierwszego dnia czwartego miesiąca po wejściu w życie zmian do rozporządzenia Rady nr 1215/2012 określających stosunek tego rozporządzenia do porozumienia JSP, w zależności od tego, które wydarzenie nastapi później. Rozporządzenie nr 1215/2012 zostało przyjęte 12 grudnia 2012 r., lecz będzie stosowane od 10 stycznia 2015 r.

${ }^{5}$ Chodzi o patenty europejskie niemające jednolitego skutku, tj. udzielane na obszar wyznaczonych przez zgłaszającego państw stron konwencji o udzielaniu patentów europejskich (dalej jako: KPE) i wymagające walidacji w tych państwach. Polska jest strona konwencji od 1 marca 2004 r. (Dz. U. 2004, Nr 79, poz. 737), a obecnie obowiąuje ona ze zmianami wprowadzonymi aktem rewidującym z 2000 r., który wszedł w życie w 2007 r. (Dz. U. 2007, Nr 236, poz. 1736).

${ }^{6}$ Dodatkowe świadectwa ochronne są udzielane na produkty lecznicze i produkty ochrony roślin na warunkach określonych w rozporządzeniu nr 469/2009 (Dz. Urz. UE L 152 z 16 czerwca 2009 r.) oraz w rozporządzeniu nr 1610/96 (Dz. Urz. WE L 190 z 8 sierpnia 1996 r.). Obecnie sa one udzielane przez krajowe urzędy patentowe i przyznają ochronę taką jak patenty krajowe. Nie jest jasne, jakie zmiany w systemie udzielania SPC spowoduje utworzenie jednolitych patentów. Lakoniczna regulacja tej kwestii jest zawarta w art. 30 porozumienia JSP.

7 Rozporządzenie Rady nr 44/2001 z 22 grudnia 2000 r. w sprawie jurysdykcji i uznawania orzeczeń sądowych oraz ich wykonywania w sprawach cywilnych i handlowych, Dz. Urz. WE L 12 z 16 stycznia 2001 r. (Bruksela I). Od 10 stycznia 2015 r. zostanie zastapione rozporządzeniem nr 1215/2012 (zob. przyp. 8).

${ }^{8}$ Rozporządzenie Parlamentu Europejskiego i Rady nr 1215/2012 z 12 grudnia 2012 r. w sprawie jurysdykcji i uznawania orzeczeń sądowych oraz ich wykonywania w sprawach cywilnych i handlowych (wersja przekształcona), Dz. Urz. UE L 351 z 20 grudnia 2012 r. Będzie stosowane od 10 stycznia 2015 r. 
Procedura uchwalenia jego zmian, o których mowa w omawianym przepisie, została wszczęta na wniosek Komisji Europejskiej z 26 lipca 2013 r. ${ }^{9}$ Można więc założyć, że rozpoczęcie stosowania „pakietu patentowego” (rozporządzeń nr 1257/12 i nr 1260/12 oraz porozumienia JSP) nastapi nie wcześniej niż w pierwszej połowie 2015 r., jeżeli porozumienie JSP zostanie ratyfikowane przez wymaganą liczbę 13 państw (chyba że TS uzna za zasadne skargi Hiszpanii w sprawach C-146/13 i C-147/13 $3^{10}$, podważające ważność rozporządzeń nr 1257/12 i nr 1260/12).

Przy ocenie porozumienia JSP należy uwzględnić wymagania konstytucyjne państw członkowskich dotyczące kompetencji w dziedzinie sprawowania władzy sądowniczej, a także takie kwestie, jak struktura wymiaru sprawiedliwości, źródła prawa stosowanego przez sądy i hierarchia tych źródeł, sposób powoływania sędziów, języki urzędowe tych państw (w Konstytucji zob. np. art. 10, art. 27 , art. 87, art. 90 i art. 175). Istotne znaczenie ma również zapewnienie poszanowania praw podstawowych, w tym prawa do obrony i rzetelnego procesu, gwarantowanych zarówno w porządkach konstytucyjnych państw członkowskich (zob. art. 45 i art. 77 ust. 2 Konstytucji), jak i w Karcie praw podstawowych Unii Europejskiej ${ }^{11}$ oraz Konwencji o ochronie praw człowieka i podstawowych wolności ${ }^{12}$.

Na utworzenie JSP (ściśle związane z ustanowieniem jednolitej ochrony patentowej) wpłynęła presja wywierana przez silnych użytkowników systemu patentowego, np. międzynarodowe koncerny, które są zainteresowane uzyskaniem możliwości ścigania naruszeń przysługujących im patentów przed jednym sądem, a nie przed sądami krajowymi państw Unii Europejskiej, a także automatyczną skutecznością i egzekwowalnością we wszystkich państwach Unii zasądzonych na ich rzecz odszkodowań i innych środków prawnych, m.in. tymczasowych i zabezpieczających.

„Klasyczne” patenty europejskie, które nadal będą mogły być udzielane na obszar wybranych przez zgłaszającego państw stron KPE i - nie mając jednolitego skutku - będą wymagały walidacji oraz dostarczenia tłumaczenia opisu patentowego do krajowego urzędu patentowego, przestana podlegać polskiej ustawie prawo własności przemysłowej ${ }^{13}$, lecz - tak jak patenty europejskie o jednolitym skutku - będą podlegać przepisom porozumienia JSP. Sprawy dotyczące tych patentów zostaną wyłączone spod jurysdykcji organów krajowych i podlegać będą wyłącznej jurysdykcji JSP (z zastrzeżeniem ewentualnych odstępstw dopuszczalnych w okresie przejściowym - zob. art. 83 porozumienia JSP).

Określone w porozumieniu JSP środki i procedury egzekwowania zarówno „klasycznych” patentów europejskich, jak i patentów europejskich o jednoli-

${ }^{9}$ KOM (2013) 554. Zob. też projekt sprawozdania komisji prawnej Parlamentu Europejskiego z 13 stycznia 2013 r. (www.parliament.europa.eu).

${ }^{10}$ Dz. Urz. UE C 171 z 15 czerwca 2013 r., s. 15-16.

11 Dz. U. 2009, Nr 203, poz. 1569 (s. 15621-15636); Dz. Urz. UE C 83 z 30 marca 2010 r. (s. 389-403).

${ }^{12}$ Konwencja, sporządzona w ramach Rady Europy w Rzymie 4 listopada 1950 r., weszła w życie w stosunku do Polski 19 stycznia 1993 r. (Dz. U. 1993, Nr 61, poz. 284 ze zm.).

${ }^{13}$ Ustawa z 30 czerwca 2000 r. (t.jedn.: Dz. U. z 29 listopada 2013 r., poz. 1410); dalej jako: p.w.p. 
tym skutku (i SPC) są podobne do tych, które zostały określone w umowie $\mathrm{ACTA}^{14}$. Na tle tego porównania widoczna jest skala, w jakiej zawarcie porozumienia JSP zaostrzy sankcje i procedury stosowane $\mathrm{w}$ razie podniesienia zarzutów naruszenia patentów (i SPC). Nie zmienia tej oceny fakt, że środki te i procedury sa podobne do tych, które zostały przewidziane w dyrektywie nr 2004/48/WE ${ }^{15}$. Dyrektywa została bowiem transponowana do właściwych ustaw polskich ${ }^{16}$, a zatem przewidziane w niej środki i procedury zostały „wpisane" w polski system prawny i sa przez sądy polskie stosowane w ramach tego systemu. Natomiast środki i procedury przewidziane w porozumieniu JSP, mimo ich werbalnego podobieństwa (nieoznaczającego jednak bynajmniej ekwiwalentności normatywnej), mają swą bezpośrednią, autonomiczna podstawę w umowie międzynarodowej (a nie w prawie krajowym) i będą stosowane przez JSP (a nie sąd krajowy), a ich stosowanie nie będzie oparte na polskim Kodeksie postępowania cywilnego, lecz na regulaminie wewnętrznym $\mathrm{JSP}^{17}$. Trudności i koszty związane z ustaleniem normatywnej treści postanowień porozumienia JSP będą szczególnie dotkliwe dla małych i średnich przedsiębiorców.

W strukturze instytucjonalnej JSP funkcje orzecznicze wykonywać będzie sąd pierwszej instancji, w ramach którego funkcjonować będą oddział centralny oraz oddziały lokalne i regionalne, a ponadto sąd apelacyjny i sekretariat. Właściwość oddziałów sądu pierwszej instancji, w tym podział spraw między oddziałem centralnym oraz oddziałami lokalnymi i regionalnymi, jest szczegółowo określona w art. 33. Wobec sporu o siedzibę oddziału centralnego (Polska, sprawując w drugim półroczu 2011 r. prezydencję w Radzie UE, zaproponowała Paryż, na co nie zgodziły się RFN i Wielka Brytania), oddział centralny został „rozczłonkowany” i będzie się mieścił w Paryżu, Londynie i Monachium. Przydział spraw ma następować według dziedziny techniki, stosownie do Międzynarodowej Klasyfikacji Patentowej ${ }^{18}$. I tak, w siedzibie oddziału centralnego w Paryżu ma się mieścić biuro prezesa sądu pierwszej instancji oraz maja być rozpoznawane sprawy patentów należących do działu B (różne procesy przemysłowe, transport), działu D (włókiennictwo, papiernictwo), działu E (budownictwo, górnictwo), działu G (fizyka) i działu H (elektrotechnika). Filia

${ }_{14}$ Zob. A. Nowicka, Umowa handlowa dotyczqca zwalczania obrotu towarami podrobionymi (ACTA) - uwagi krytyczne, w: P. Grzegorczyk, K. Knoppek, M. Walasik (red.), Proces cywilny. Nauka - kodyfikacja - praktyka. Ksiega jubileuszowa dedykowana Profesorowi Feliksowi Zedlerowi, Warszawa 2012, s. 1167 i n.

15 Dyrektywa nr 2004/48/WE z 29 kwietnia 2004 r. w sprawie egzekwowania praw własności intelektualnej (Dz. Urz. UE L 195 z 2 czerwca 2004 r.).

${ }_{16}$ Zob. ustawę z 9 maja 2007 r. (Dz. U. Nr 99, poz. 662), która wprowadziła zmiany m.in. do ustawy z 30 czerwca 2000 r. - Prawo własności przemysłowej (t. jedn.: Dz. U. z 29 listopada 2013 r., poz. 1410).

17 Według art. 41 porozumienia JSP, regulamin wewnętrzny ma określać „,szczegóły prowadzenia postępowań” przed tym sądem. Zostanie on przyjęty przez komitet administracyjny, a więc dopiero po wejściu w życie porozumienia JSP. Piętnasty projekt regulaminu, opatrzony datą 31 maja 2013 r., jest dostępny (w języku angielskim) na: www.unified-patent-court.org.

18 Ustanowionej w ramach Światowej Organizacji Własności Intelektualnej (WIPO) na mocy Porozumienia strasburskiego dotyczącego międzynarodowej klasyfikacji patentowej z 1971 r. (Dz. U. 2003, Nr 63, poz. 579). Aktualna wersja jest dostępna na: www.wipo.int/classifications/ipc/en. 
oddziału centralnego w Londynie ma być właściwa dla patentów należących do działu A (podstawowe potrzeby ludzkie) i działu C (chemia, metalurgia), a filia w Monachium - dla patentów należących do działu F (budowa maszyn, oświetlenie, ogrzewanie, uzbrojenie, technika minerska).

\section{STATUS PRAWNY JEDNOLITEGO SĄDU PATENTOWEGO I JEGO POZYCJA W ŚWIETLE PRAWA UNII EUROPEJSKIEJ}

Wskazując, z jednej strony, na ścisłe sprzężenie porozumienia JSP z unijnymi rozporządzeniami wprowadzajaccymi wzmocnioną współpracę $\mathrm{w}$ omawianej dziedzinie ( $\mathrm{nr}$ 1257/12 i nr 1260/12), z drugiej strony podkreślić należy okoliczność, że mimo tego sprzężenia utworzenie JSP nie następuje na podstawie aktu Unii Europejskiej, w ramach wzmocnionej współpracy, lecz poza nia - na płaszczyźnie prawa międzynarodowego. Omawiana umowa nie jest częścia unijnego acquis i nie uczestniczy w niej Unia Europejska, co oznacza m.in., że ani ocena jej zgodności z traktatami, ani wykładnia jej postanowień nie sa objęte kognicją Trybunału Sprawiedliwości (TS).

Status prawny JSP jest istotny w kontekście oceny zgodności umowy międzynarodowej tworzącej ten sąd zarówno z prawem Unii Europejskiej, jak i z Konstytucją. Na gruncie prawa Unii chodzi np. o dopuszczalność zawarcia porozumienia JSP przez państwa członkowskie oraz występowanie przez JSP z pytaniami prejudycjalnymi do TS. Natomiast na gruncie Konstytucji chodzi zwłaszcza o dopuszczalność przekazania przez Polskę władzy sądowniczej na rzecz JSP i zgodność porozumienia JSP z ustrojową zasadą sprawowania wymiaru sprawiedliwości w Polsce.

Należy uwzględnić fakt, że poprzednio przewidywana umowa międzynarodowa mająca utworzyć sąd ds. patentów europejskich i patentów unijnych (EEUPC) ${ }^{19}$, została zakwestionowana przez TS w opinii 1/09 z 8 marca $2011 \mathrm{r}^{20}$ jako niezgodna $\mathrm{z}$ unijnymi traktatami. $\mathrm{Z}$ tego powodu w porozumieniu JSP odstapiono od niektórych wcześniej przyjętych założeń, w szczególności umowa tworząca JSP ma być zawarta tylko przez państwa członkowskie; inaczej niż poprzednio, nie uczestniczy w niej, jak wspomniano, ani Unia Europejska, ani te państwa strony KPE, które nie należą do Unii (chodzi o dziesięć państw, m.in. Szwajcarię, Norwegię, Turcję).

Z opinii 1/09 wynika, że jednym z istotnych powodów podważenia poprzednio przewidywanej umowy było uznanie przez TS, że nie gwarantowała ona pierwszeństwa prawa Unii Europejskiej, a EEUPC znajdował się poza jej ramami instytucjonalnymi i systemem sądowniczym. Według TS sąd patentowy nie był częścia systemu sądowniczego określonego w art. 19 ust. 1 TUE, lecz stanowił organizacją dysponującą własną osobowością prawną na mocy pra-

${ }^{19}$ European and Community Patents Court; po wejściu w życie Traktatu z Lizbony (1 grudnia 2009 r.) chodziło o sąd ds. patentów europejskich i patentów Unii Europejskiej (European and European Union Patents Court). Projekt porozumienia tworzącego EEUPC był zawarty dokumencie Rady nr 7928/09 z 23 marca 2009 r.

${ }^{20}$ Dz. Urz. UE C 211 z 16 lipca 2011 r., s. 2 (uzasadnienie opinii: www.curia.europa.eu). 
wa międzynarodowego. Przytaczając sprawy mające się mieścić w wyłącznej jurysdykcji sądu, Trybunał zaznaczył, że w odniesieniu do tych spraw sądy umawiających się państw członkowskich zostałyby pozbawione jurysdykcji i zachowały jedynie kompetencje w obszarze, który nie byłby objęty wyłączna jurysdykcją sądu patentowego. Istotny był fakt, że EEUPC byłby zobowiązany do dokonywania wykładni i stosowania prawa Unii. Sąowi temu zostałaby przyznana zasadnicza część przysługujących sądom krajowym kompetencji do rozstrzygania sporów z zakresu patentu unijnego i zapewnienia pełnego stosowania prawa Unii $\mathrm{w}$ tej dziedzinie, jak również ochrony sądowej praw podmiotowych wywodzonych z prawa Unii.

W opiniowanej umowie TS dostrzegł rozwiązania, które pociagnęły za sobą jej zakwestionowanie. Jak wskazał Trybunał, EEUPC zastapiłby sądy krajowe w zakresie objętym przysługująca mu jurysdykcją wyłączną i pozbawiłby sądy krajowe możliwości zwracania się do TS z pytaniami prejudycjalnymi $\mathrm{w}$ tej dziedzinie. Ponadto stałby się w zakresie przysługującej mu jurysdykcji wyłącznej jedynym sądowniczym partnerem dialogu z TS, w ramach trybu prejudycjalnego, w kwestiach wykładni i stosowania prawa Unii oraz miałby za zadanie w ramach swej jurysdykcji dokonywać wykładni prawa Unii i je stosować.

Również na tle porozumienia JSP wątpliwości co do statusu JSP są istotne zwłaszcza w kontekście art. 267 TfUE, ustanawiającego prawo, a w określonej sytuacji - obowiązek sądów krajowych występowania do TS z wnioskami o wydanie orzeczeń w trybie prejudycjalnym. W kontekście powołanego przepisu rodzi się pytanie, czy JSP może być traktowany jako „sąd państwa członkowskiego" (sąd krajowy). Aby dokonać takiej kwalifikacji, nie wystarcza ani postanowienie, że JSP jest „sądem wspólnym dla umawiających się państw członkowskich, a zatem podlega tym samym zobowiąaniom na podstawie prawa Unii, co każdy sąd krajowy tych państw” (art. 1), ani określenie, że JSP jako „sąd wspólny dla umawiających się państw członkowskich” jest „częśscią ich systemu sądowego" (art. 21). Zamieszczenie tych postanowień w porozumieniu JSP nie zmienia natury sądu - jako sądu międzynarodowego mającego własną osobowość prawną (art. 4) ani nie włącza go do struktury sądowej państw członkowskich, ani wreszcie nie zapewnia jakiejkolwiek więzi funkcjonalnej z krajowymi systemami sądowymi tych państw.

Porozumienie JSP nie usuwa obiekcji TS wyrażonych pod adresem EEUPC w konkluzji opinii 1/09, w której uznano, że „planowane porozumienie, przewidując przyznanie wyłącznej właściwości do rozstrzygania określonych rodzajów powództw wnoszonych przez jednostki w dziedzinie patentu wspólnotowego oraz do dokonywania wykładni i stosowania prawa Unii w tej dziedzinie międzynarodowemu organowi sądowemu [powinno być: sądowi międzynarodowemu - dop. A.N.] ${ }^{21}$, który nie jest osadzony w instytucjonalnych i sądowniczych ramach Unii, pozbawiłoby sądy państw członkowskich ich kompetencji w zakresie dokonywania wykładni i stosowania prawa Unii, a Trybunał jego właściwości do udzielania w ramach trybu prejudycjalnego odpowiedzi na za-

21 TS określił EEUPC jako „sąd międzynarodowy” (international court; internationale Gericht). W polskiej wersji opinii 1/09 użyto nietrafnie zwrotu „międzynarodowy organ sądowy”. 
dawane przez te sądy pytania, a w rezultacie zmieniłoby kluczowe dla zapewnienia istoty prawa Unii kompetencje instytucji Unii i państw członkowskich przyznane im na mocy traktatów".

Obiekcji tych nie usuwają również pozostałe postanowienia porozumienia JSP, majacce stanowić remedium na zastrzeżenia TS dotyczące braku gwarancji poszanowania przez JSP prawa Unii i jego pierwszeństwa. Chodzi o przepisy rozdziału IV regulującego pierwszeństwo prawa Unii, odpowiedzialność prawną i obowiązki umawiających się państw członkowskich. Na rozdział ten składaja się art. 20-23 (dwa ostatnie artykuły dotyczą odpowiedzialności za naruszenie prawa Unii i są omówione poniżej).

Przepis art. 20 porozumienia JSP (opatrzony nagłówkiem „Pierwszeństwo prawa Unii i jego poszanowanie”) stanowi, że JSP stosuje prawo Unii w całości i uznaje jego pierwszeństwo. W art. 21 podjęto próbę „wkomponowania” JSP $\mathrm{w}$ unijny system sądowy $\mathrm{w}$ aspekcie występowania przez JSP do TS z wnioskami w trybie prejudycjalnym. Przepis ten stanowi: „Jako sąd wspólny dla umawiających się państw członkowskich i część ich systemu sądowego Sąd współpracuje z Trybunałem Sprawiedliwości Unii Europejskiej, by zapewnić prawidłowe stosowanie i jednolitą wykładnię prawa Unii, tak jak każdy sąd krajowy, zgodnie w szczególności z art. 267 TfUE. Orzeczenia Trybunału Sprawiedliwości Unii Europejskiej są dla Sądu wiążące”.

Sprawę występowania z pytaniami prejudycjalnymi do TS reguluje art. 38 statutu JSP (załącznik I do porozumienia JSP), który w ust. 1 stanowi, że stosuje się procedury ustalone przez TSUE dla spraw rozpatrywanych w trybie prejudycjalnym w ramach Unii Europejskiej. Z kolei w ust. 2 przewiduje się, że sąd pierwszej instancji oraz sąd apelacyjny zawiesza postępowanie w chwili postanowienia o przekazaniu do TSUE pytania w sprawie wykładni TUE lub TfUE, lub pytania dotyczącego ważności lub wykładni aktów instytucji Unii.

Wskazując na niejasny status JSP w prawie Unii, zaznaczyć należy, że art. 118 TfUE, obrany jako podstawa prawna obu rozporządzeń wprowadzających wzmocnioną współpracę w omawianej dziedzinie, jest powiązany z art. $262 \mathrm{TfUE}^{22}$, który mógłby stanowić podstawę prawną utworzenia sądu ds. patentu unijnego (obecnie: patentu europejskiego o jednolitym skutku, mającego obowiązywać w państwach uczestniczących we wzmocnionej współpracy). Jednym z powodów nieskorzystania z podstawy prawnej, jaką stanowi art. 262 TfUE, jest zapewne fakt, że JSP ma mieć wyłączną kompetencję nie tylko w sprawach dotyczących patentów europejskich o jednolitym skutku, lecz także „klasycznych” patentów europejskich. Nasuwa się jednak wątpliwość, czy - wobec obowiązywania tej regulacji traktatowej - dopuszczalne jest utworzenie JSP przez państwa członkowskie (w zakresie kompetencji orzeczniczych dotyczących patentu europejskiego o jednolitym skutku), z pominię-

${ }^{22}$ Według art. 262 TfUE, bez uszczerbku dla innych postanowień traktatów, Rada, stanowiąc jednomyślnie zgodnie ze specjalną procedurą ustawodawczą i po konsultacji z Parlamentem Europejskim, może przyjąć postanowienia w sprawie przyznania TSUE, w określonym przez nią zakresie, właściwości w odniesieniu do sporów dotyczących stosowania aktów przyjętych na podstawie traktatów, które tworzą europejskie tytuły prawne w dziedzinie własności intelektualnej. Postanowienia te wchodzą w życie po ich zatwierdzeniu przez państwa członkowskie, zgodnie z ich odpowiednimi wymogami konstytucyjnymi. 
ciem unijnej procedury określonej w art. 262 TfUE. Kwestia ta była analizowana w opinii 1/09 w odniesieniu do poprzednio planowanego sądu (EEUPC), a TS zają liberalne stanowisko, uznając, że art. 262 TfUE przewiduje możliwość rozszerzenia właściwości sądów Unii na spory związane ze stosowaniem aktów Unii tworzących europejskie tytuły własności intelektualnej, a w konsekwencji „nie ustanawia on monopolu Trybunału w rozpatrywanej dziedzinie i nie przesądza o wyborze systemu sądowniczego, w ramach którego winny być rozstrzygane spory między jednostkami w zakresie tytułów własności intelektualnej"23.

Wątpliwość dotycząca dopuszczalności zawarcia porozumienia JSP przez państwa członkowskie wiąże się z kwalifikacją tej umowy międzynarodowej do określonej kompetencji Unii Europejskiej. Dziedziny, w których Unia ma wyłączną kompetencję, wymienia art. 3 TfUE, wskazując w ust. 1: unię celna, ustanawianie reguł konkurencji niezbędnych do funkcjonowania rynku wewnętrznego, politykę pieniężną w odniesieniu do państw członkowskich, których waluta jest euro, zachowanie morskich zasobów biologicznych w ramach wspólnej polityki rybołówstwa, wspólną politykę handlową. Można przyjaćc, że zawarcie porozumienia JSP nie mieści się w żadnej z tych dziedzin.

W kontekście porozumienia JSP uwagę należy jednak skupić na art. 3 ust. 2 TfUE, zgodnie z którym Unia ma także wyłączną kompetencję do zawierania umów międzynarodowych, jeżeli ich zawarcie zostało przewidziane w akcie ustawodawczym Unii lub jest niezbędne do umożliwienia Unii wykonywania jej wewnętrznych kompetencji lub w zakresie, w jakim ich zawarcie może wpływać na wspólne zasady lub zmieniać ich zakres.

Zasadna wydaje się teza, że zawarcie porozumienia JSP „może wpływać na wspólne zasady lub zmieniać ich zakres", przy czym w rachubę wchodza w szczególności „wspólne zasady” (common rules) ${ }^{24} \mathrm{w}$ dziedzinie zbliżenia ustawodawstw, określone w art. 118 TfUE, obranym jako podstawa prawna obu rozporządzeń wprowadzajacych wzmocnioną współpracę w dziedzinie tworzenia jednolitej ochrony patentowej.

Ponadto powyższa teza opiera się na stanowisku zakładającym wyłączny charakter kompetencji Unii Europejskiej w tych dziedzinach, w których wykonała już ona kompetencje (tzw. wyłączność by exercise), wobec czego zawarcie umowy międzynarodowej może „wpływać na wspólne zasady lub zmieniać ich zakres", jak to ujmuje art. 3 ust. 2 TfUE $^{25}$. Jedna z takich dziedzin jest jurysdykcja oraz uznawanie i wykonywanie orzeczeń sądowych, m.in. w sprawach dotyczących patentów (obecnie: patentów europejskich i patentów krajowych), uregulowana rozporządzeniem nr 44/2001. Okoliczność, że Unia wykonała kompetencje w tej dziedzinie (również zresztą w innych, np. objętych dyrektywą nr 2004/48/WE) skłania do oceny, że ma ona wyłączną kompetencję.

\footnotetext{
23 Zob. pkt 62 opinii.

${ }^{24}$ Zaznaczyć trzeba brak jednolitości terminologicznej polskiej wersji TfUE. O ile w nagłówku tytułu VII TfUE na określenie common rules użyto w wersji polskiej zwrotu „wspólne reguły”, o tyle w art. 3 ust. 2 TfUE określenie to przełożono jako „wspólne zasady”.

${ }_{25}$ Podobne ujęcie zastosował ETS w orzeczeniu z 31 marca 1971 r. w sprawie 22/70 Commission of the European Communities $v$. Council of the European Communities (ERTA case).
} 
Przyjęcie powyższych ocen oznaczałoby, że zawarcie porozumienia JSP jest objęte wyłączną kompetencją Unii Europejskiej, a zatem niedopuszczalne jest jego zawarcie przez państwa członkowskie. Warto zaznaczyć, że jednym z następstw faktu, iż Unia nie uczestniczy w porozumieniu JSP, była niemożność skierowania tej umowy międzynarodowej pod osąd TS na podstawie art. 218 ust. 11 TfUE. Innym skutkiem braku uczestnictwa Unii w porozumieniu JSP jest fakt, że nie będzie ona partycypować w kosztach JSP, a zatem ciężar finansowy związany z jego utworzeniem i działaniem będą ponosić państwa członkowskie.

W opinii 1/09 TS podkreślił również zasadę odpowiedzialności majątkowej państwa członkowskiego za szkody wyrządzone jednostkom w związku z naruszeniem prawa Unii. Dodał, że w wypadku gdy naruszenia prawa Unii dopuszcza się sąd krajowy, art. 258-260 TfUE przewidują możliwość wystąpienia do Trybunału celem stwierdzenia takiego uchybienia. W odniesieniu do EEUPC, TS stwierdził: „Orzeczenie sądu patentowego, które naruszałoby prawo Unii, nie mogłoby być natomiast przedmiotem postępowania w sprawie uchybienia zobowiązaniom państwa członkowskiego ani prowadzić do powstania jakiejkolwiek odpowiedzialności majątkowej jednego lub kilku z państw członkowskich"26.

Próbując znaleźć remedium na tę obiekcję, w porozumieniu JSP przewidziano solidarna odpowiedzialność umawiających się państw członkowskich za szkody wynikłe z naruszenia prawa Unii przez sąd apelacyjny JSP. Określa ją art. 22, stanowiąc w ust. 1, że umawiające się państwa członkowskie ponoszą tę odpowiedzialność zgodnie z prawem Unii dotyczacym odpowiedzialności pozaumownej państw członkowskich za szkody spowodowane naruszeniem prawa Unii przez ich sądy krajowe (art. 22 ust. 2 określa państwo, przeciwko któremu wnosi się sprawę o odszkodowanie).

Rozwiąanie to nie nadaje się do zaakceptowania. Nie sposób bowiem zgodzić się na to, aby np. Polska była solidarnie odpowiedzialna za szkody wyrządzone przez sąd apelacyjny JSP w Luksemburgu w sprawie niemającej żadnego związku z naszym krajem (np. szkoda zostanie przez ten sąd wyrzadzona podmiotowi belgijskiemu w sprawie o naruszenie patentu należącego do podmiotu japońskiego, dokonane na terytorium Francji).

Nie do przyjęcia jest również regulacja dotycząca tzw. regresu. W art. 22 ust. 3 porozumienia JSP przewidziano, że umawiajace się państwo członkowskie, które wypłaciło odszkodowanie, jest uprawnione do otrzymania od pozostałych umawiających się państw proporcjonalnego wkładu ustalonego zgodnie z metodą określoną w art. 37 ust. 3 i 4, przy czym szczegółowe przepisy regulujące wkład umawiajaccych się państw członkowskich na podstawie niniejszego ustępu ma ustalać komitet administracyjny.

Z powyższą kwestią wiąże się art. 23 (opatrzony nagłówkiem „odpowiedzialność umawiających się państw członkowskich”), który stanowi, że działania JSP są bezpośrednio przypisywane każdemu umawiającemu się państwu członkowskiemu z osobna, również do celów art. 258, 259 i $260 \mathrm{TfUE}^{27}$, oraz

26 Zob. pkt 88 opinii.

27 Przepisy te reguluja postępowanie oraz kary pieniężne, przybierające postać tzw. ryczałtu (lump sum) lub okresowej kary pieniężnej (penalty payment), jakie są nakładane na państwo członkowskie w razie ustalenia, że uchybiło ono zobowiązaniom wynikającym z unijnych traktatów. 
wspólnie wszystkim umawiającym się państwom członkowskim. Również to postanowienie budzi sprzeciw z powodów wskazanych wyżej. Niejasne jest też samo sformułowanie (działania JSP mają być przypisywane każdemu państwu z osobna i wszystkim państwom wspólnie), a także zasady egzekwowania owej indywidualno-kolektywnej „przypisywalności” (np. proporcja, w jakiej poszczególne państwa mają uiszczać kary pieniężne nałożone na podstawie art. 260 TfUE).

Podsumowując, porozumienie JSP nie usuwa wątpliwości dotyczących charakteru sądu i jego pozycji w systemie sądowniczym Unii Europejskiej, ani w kontekście art. 267 TfUE, ani w kontekście art. 258-260 TfUE. Zamieszczenie $\mathrm{w}$ omawianej umowie międzynarodowej sformułowań określających JSP jako „sąd wspólny dla umawiających się państw członkowskich” czy „część ich systemu sądowego" nie lokuje go w strukturze sądowniczej państw członkowskich ani nie zapewnia jakiejkolwiek więzi funkcjonalnej z krajowymi systemami sądowymi.

\section{ZASTRZEŻENIA CO DO ZGODNOŚCI Z KONSTYTUCJĄ}

Porozumienie JSP budzi zasadnicze zastrzeżenia co do zgodności z Konstytucją. Jednolity Sąd Patentowy nie mieści się w strukturze polskiego wymiaru sprawiedliwości, określonej w rozdziale VIII Konstytucji. Nie jest ani sądem, ani trybunałem w rozumieniu Konstytucji, wobec czego orzekanie przez JSP pozostawać będzie w sprzeczności z zasadą ustrojową wyrażoną w art. 10 ust. 2, zgodnie z którą „władzę sądowniczą sprawują sądy i trybunały”. Jest to sprawa bezprecedensowa, której nie można porównywać ani z kompetencjami TSUE, ani Międzynarodowego Trybunału Karnego ${ }^{28}$. W stosunku do JSP chodzi bowiem o wyzbycie się przez państwo władzy sądowniczej (władztwa jurysdykcyjnego) w sporach prywatnoprawnych między jednostkami - osobami fizycznymi, prawnymi i innymi podmiotami. Sprawowanie władzy sądowniczej na własnym terytorium jest jednym z zasadniczych atrybutów państwa, a wykonywanie jurysdykcji stanowi gwarancję jednego z praw podstawowych, jakim jest prawo do sądu (art. 45 Konstytucji).

Dopuszczenie jurysdykcji JSP będzie niezgodne z zasadą ustrojową ustanowioną w art. 175 ust. 1 Konstytucji, zgodnie z która ,wymiar sprawiedliwości w Rzeczypospolitej Polskiej sprawują Sąd Najwyższy, sądy powszechne, sądy administracyjne oraz sądy wojskowe”. Jednolity Sąd Patentowy nie mieści się w żadnej z powyższych kategorii.

Biorąc pod uwagę status prawny JSP, zwłaszcza przytoczoną wyżej formułę, według której jest on „sądem wspólnym dla umawiających się państw członkowskich", nie sposób go umiejscowić w polskim systemie władzy sądowniczej. Należy mieć na uwadze, że zarówno powyższe określenie, jak i formuła, według której JSP stanowi „część systemu sądowego” umawiających się państw członkowskich, zostały zastosowane na użytek prawa Unii Europej-

${ }^{28}$ Zob. szerzej A. Nowicka, R. Skubisz, Pakiet patentowy (ocena z perspektywy Polski), „Europejski Przegląd Sądowy” 2013, nr 4, s. 19-20. 
skiej i przez twórców porozumienia JSP zostały uznane za wystarczające do uchylenia zastrzeżeń TS wyrażonych w opinii 1/09 (zob. wyżej w pkt II).

Powyższe zabiegi nie wystarczaja jednak do uznania JSP za część polskiego systemu sądowego na gruncie naszego porządku konstytucyjnego. System ten jest określony w Konstytucji, a jej przepisy nie przewidują istnienia „sądu wspólnego dla państw członkowskich”. Wbrew Konstytucji, umowa międzynarodowa nie może rozstrzygać o tym, czy jakikolwiek sąd, tworzony tą umowa, jest częścia polskiego systemu sądowego. Sformułowanie, że JSP jest częścią (polskiego) systemu sądowego jest więc niezgodne z zasadą dotyczącą sprawowania wymiaru sprawiedliwości, wyrażoną w art. 175 Konstytucji.

Jednolity Sąd Patentowy nie będzie wydawał wyroków „w imieniu Rzeczypospolitej Polskiej”, o czym stanowi art. 174 Konstytucji. Inaczej niż wszystkie sądy i trybunały, o których mowa w Konstytucji, JSP będzie odrębną od państwa strukturą sądowa, wyposażoną w osobowość prawną (zob. art. 4 porozumienia JSP).

Porozumienie JSP zakłada przekazanie na rzecz JSP władzy sądowniczej, o której mowa w art. 10 ust. 2 Konstytucji, w indywidualnych sprawach dotyczących patentów europejskich i przyszłych patentów europejskich o jednolitym skutku (i SPC). Tymczasem w świetle art. 90 Konstytucji ${ }^{29} \mathrm{i}$ orzecznictwa Trybunału Konstytucyjnego przekazanie tej kompetencji - władztwa jurysdykcyjnego - uznać należy za niedopuszczalne ${ }^{30}$.

W związku z art. 90 Konstytucji wskazać należy, po pierwsze, że określa on ramy prawne przekazania przez państwo kompetencji organów władzy państwowej w niektórych sprawach na rzecz „organizacji międzynarodowej” lub „organu międzynarodowego”, a zatem wstępnym warunkiem przekazania kompetencji na rzecz JSP musiałoby być zakwalifikowanie tego sądu do jednej z wymienionych kategorii ${ }^{31}$. Tymczasem trudno dostrzec podstawę do takiej kwalifikacji. Raczej JSP trzeba uznać za „sąd międzynarodowy” (jak to uczynił TS w opinii 1/09 w stosunku do poprzednio planowanego sądu ds. patentów europejskich i unijnych), co nie jest tożsame z uznaniem za „organizację” (bądź „organ”) międzynarodowy ${ }^{32}$. Sprawę dodatkowo komplikuje użyta w porozumieniu JSP formuła określająca ten sąd jako „sąd wspólny dla umawiających się państw członkowskich" (niezależnie od tego, co formuła ta oznacza na użytek prawa Unii Europejskiej, w tym art. 258-260 i art. 267 TfUE).

Po drugie, nawet gdyby uznać JSP za „organizację” (,organ”) międzynarodowy, to przeciwko dopuszczalności przekazania kompetencji na rzecz JSP przemawia ich rodzaj (charakter). Przekazaniu miałyby podlegać kompetencje leżące w sferze władzy sądowniczej, o której mowa w art. 10 ust. 2 Konstytu-

${ }^{29}$ Stosownie do art. 90 ust. 1 Konstytucji: „Rzeczpospolita Polska może na podstawie umowy międzynarodowej przekazać organizacji międzynarodowej lub organowi międzynarodowemu kompetencje organów władzy państwowej w niektórych sprawach".

${ }^{30}$ Zob. wyroki TK z 11 maja 2005 r., K 18/04 oraz z 24 listopada 2010 r., K 32/09.

${ }^{31} \mathrm{~W}$ wyroku z 24 listopada 2010 r., K 32/09, TK uznał za niedopuszczalne przekazanie kompetencji innemu podmiotowi aniżeli organizacja międzynarodowa lub organ międzynarodowy.

32 Jak wskazano wyżej, w polskiej wersji opinii 1/09 dystynkcja ta nie jest przestrzegana (ang. termin international court, niem. internationale Gericht przetłumaczono jako „międzynarodowy organ sądowy”, gdy tymczasem oba terminy oznaczaja „,sąd międzynarodowy”). 
cji, a zatem polegające na sprawowaniu wymiaru sprawiedliwości. Wymiar sprawiedliwości jest kompetencja, którą Trybunał Konstytucyjny uznał za składającą się na „istotę suwerenności”, wyznaczająca granice przekazywania kompetencji (zob. wyrok z 24 listopada 2010 r., K 32/09, pkt III.2.2 uzasadnienia). Pogląd ten, wyrażony w kontekście członkostwa w Unii Europejskiej, trzeba w pełni odnieść również do JSP, niezależnie od niejasności dotyczących jego statusu prawnego. Wspomniane stanowisko Trybunału Konstytucyjnego wiąże się z uznaniem, że „suwerenność Rzeczypospolitej wyraża się w nieprzekazywalnych kompetencjach organów władzy państwowej, stanowiących o tożsamości konstytucyjnej państwa" ${ }^{33}$.

Po trzecie, rozważając znaczenie użytego w art. 90 ust. 1 Konstytucji zwrotu „przekazanie kompetencji w niektórych sprawach”, Trybunał Konstytucyjny podtrzymał w powołanym wyżej wyroku z 24 listopada 2010 r. pogląd, wyrażony we wcześniejszym orzecznictwie (zwłaszcza w wyroku z 11 maja 2005 r., K 18/04), że „przekazanie kompetencji »w niektórych sprawach« rozumiane musi być zarówno jako zakaz przekazywania ogółu kompetencji danego organu, przekazania kompetencji w całości spraw w danej dziedzinie, jak i jako zakaz przekazania kompetencji co do istoty spraw określających gestie danego organu władzy państwowej”. Także w tym aspekcie przekazanie kompetencji w sferze wymiaru sprawiedliwości na rzecz JSP uznać należy za niedopuszczalne. Jak bowiem wynika z art. 3 i art. 32 porozumienia JSP, sąd ten ma mieć wyłączną kompetencję w niemal wszystkich sprawach dotyczaccych „klasycznego” patentu europejskiego oraz patentu europejskiego o jednolitym skutku (i SPC). Sprawy wymienione w tych przepisach niewątpliwie stanowia ,istotę" spraw patentowych.

Ponadto, zgodnie ze stanowiskiem Trybunału Konstytucyjnego, przekazanie kompetencji nie może naruszać postanowień Konstytucji, w tym zasady jej nadrzędności w systemie źródeł prawa ${ }^{34}$. Tymczasem porozumienie JSP jest niezgodne z tą zasada, gdyż - określając w art. 24 źródła prawa, którymi będzie związany JSP - na czele tych źródeł stawia prawo Unii Europejskiej (w tym rozporządzenia nr 1257/12 i 1260/12) i - na drugim miejscu - porozumienie JSP. Budzi to zastrzeżenia co do zgodności z zasadą konstytucyjna wyrażoną w art. 8 ust. 1, według której Konstytucja jest najwyższym prawem Rzeczypospolitej Polskiej, a także z hierarchią źródeł prawa określona w art. 87 Konstytucji ${ }^{35}$.

${ }^{33}$ Zob. wyrok TK z 24 listopada 2010 r., K 32/09, pkt III.2.1 uzasadnienia. Zdaniem TK tożsamość konstytucyjna jest „pojęciem wyznaczającym zakres »wyłączenia spod kompetencji przekazania materii należących [...] do 'twardego jądra', kardynalnych dla podstaw ustroju danego państwa« [...]".

${ }^{34}$ Tak TK w wyroku z 24 listopada 2010 r., K 32/09, pkt III.2.6 uzasadnienia.

35 Według utrwalonego stanowiska TK: „Konstytucja pozostaje - z racji swej szczególnej mocy - "prawem najwyższym Rzeczypospolitej Polskiej« w stosunku do wszystkich wiążących Rzeczpospolitą Polską umów międzynarodowych. Dotyczy to także ratyfikowanych umów międzynarodowych o przekazaniu kompetencji "w niektórych sprawach«. Z racji wynikającej z art. 8 ust. 1 Konstytucji nadrzędności mocy prawnej korzysta ona na terytorium Rzeczypospolitej Polskiej z pierwszeństwa obowiązywania i stosowania" (zob. cyt. wyżej wyrok z 24 listopada 2010 r., pkt III.2.6 uzasadnienia). Stanowisko takie TK zajął również w wyroku z 16 listopada 2011 r., 
Zastrzeżenia budzą projektowane rozwiązania dotyczące składów orzekających, np. w oddziałach lokalnych czy regionalnych, w tym kwestia wielonarodowej obsady sędziowskiej, kwestia sędziów o kwalifikacjach technicznych czy sposób powoływania sędziów, niezgodny z art. 179 Konstytucji. Przepis ten, rzecz jasna, dotyczy sędziów „sądów i trybunałów”, o których mowa w rozdziale VIII Konstytucji (o sędziach jakichkolwiek innych sądów, w rodzaju JSP, Konstytucja w ogóle nie wspomina). Nawet gdyby próbowano minimalizować tę niezgodność za pomocą argumentu, że art. 179 Konstytucji nie dotyczy JSP, gdyż nie jest on „sądem” w rozumieniu tego artykułu, to nieusuwalna przeszkodę do związania się porozumieniem JSP stanowią powołane wyżej art. $90 \mathrm{i}$ art. 175 ust. 1 Konstytucji.

Zastrzeżenia budzą również regulacje dotyczące języków postępowania przed oddziałami lokalnymi bądź regionalnymi, oddziałem centralnym, sadem apelacyjnym w Luksemburgu (art. 49-50 porozumienia JSP). Jak stanowi art. 27 Konstytucji, „w Rzeczypospolitej Polskiej językiem urzędowym jest język polski”. Tymczasem porozumienie JSP, jakkolwiek przewiduje prowadzenie postępowań przed oddziałem lokalnym w języku urzędowym państwa, w którym mieści się ten oddział, to jednak dopuszcza przypadki, w których postępowania będa się toczyć w języku obcym, i to nawet w położonym w Polsce oddziale lokalnym (jeśli doszłoby do jego utworzenia). Godzi to w prawo do obrony i rzetelnego procesu, gwarantowane w art. 45 ust. 1 i art. 77 ust. 2 Konstytucji. Przepisy porozumienia JSP moga np. prowadzić do sytuacji, w których - nawet w oddziale lokalnym działajaccym w naszym kraju - postępowanie o naruszenie patentu przeciwko podmiotowi polskiemu będzie prowadzone w języku obcym. Z kolei postępowania przed oddziałem centralnym (mającym rozpoznawać m.in. sprawy o unieważnienie patentów) będą się zawsze toczyć w języku obcym (ma to być język, w którym udzielono patentu, tj. jeden z języków Europejskiego Urzędu Patentowego: angielski, francuski albo niemiecki). Orzeczenia JSP mają być wydawane w języku postępowania, a zatem ilekroć będzie nim język obcy, również orzeczenie zostanie wydane w tym języku.

Regulacje dotyczące języków postępowania godzą również w prawa podstawowe, w tym prawo do obrony i rzetelnego procesu (obejmujące m.in. prawo do wysłuchania), gwarantowane w art. 45 ust. 1 i art. 77 ust. 2 Konstytucji, a także w art. 6 Konwencji o ochronie praw człowieka i podstawowych wolności oraz w art. 47 Karty praw podstawowych UE.

Sposób zapewnienia prawa do obrony i rzetelnego procesu nasuwa też zastrzeżenia w kontekście przepisów dotyczących tłumaczeń dokumentów i rozpraw (art. 51 porozumienia JSP). Nie należy tracić z pola widzenia faktu, że w sprawach patentowych występuje zwykle znaczna liczba trudnych językowo dokumentów, wymagajacych specjalistycznej wiedzy z poszczególnych dziedzin techniki (opisy patentowe, opinie biegłych, opisy procesów technologicznych, publikacje podważające nowość czy poziom wynalazczy spornego wynalazku). Ponadto koszty tłumaczeń obciążać będą zwykle stronę przegrywająca;

SK 45/09, ponownie stwierdzając, że Konstytucja zachowuje „nadrzędność i pierwszeństwo wobec wszystkich aktów prawnych obowiązujących w polskim porządku konstytucyjnym, w tym także prawa unijnego". 
oprócz innych negatywnych następstw przegrania procesu poniesie ona koszty należnych jej tłumaczeń.

Zastrzeżenia co do zgodności z konstytucyjnymi standardami prawa do sądu budzą regulacje postępowań przed JSP (zob. wspomniany wyżej 15. projekt regulaminu wewnętrznego). Są one niezmiernie skomplikowane i niejasne oraz nie zapewniają należytej pozycji podmiotów pochodzących z państw, których językami urzędowymi są języki inne niż angielski, francuski i niemiecki.

\section{UWAGI KOŃCOWE}

Jak wspomniano, Polska dotychczas nie podpisała porozumienia JSP. W świetle wskazanych wyżej zastrzeżeń co do zgodności z Konstytucja, ratyfikowanie tej umowy wymagałoby uprzednich zmian Konstytucji.

Niezależnie od względów prawnych należy mieć na uwadze niekorzystne konsekwencje ekonomiczne i społeczne. Po pierwsze, związanie się porozumieniem JSP spowoduje skuteczność patentów europejskich o jednolitym skutku $\mathrm{w}$ Polsce $^{36}$. Po drugie, dla podmiotów polskich jurysdykcja JSP oznaczałaby ograniczenie dostępu do sądu, poważny wzrost kosztów postępowań, utrudnienie obrony przed zarzutami naruszenia cudzych praw. Sprawy patentowe (i dotyczące dodatkowych praw ochronnych), zostałyby wyłączone spod jurysdykcji organów krajowych i poddane wyłącznej jurysdykcji JSP. Postępowania przed tym sądem w większości przypadków będą się toczyły za granica, np. w oddziale centralnym w Paryżu, Londynie lub Monachium, tudzież w instancji apelacyjnej w Luksemburgu. Wyjątkowo, i to pod warunkiem, że w Polsce zostałby utworzony oddział lokalny JSP (co bynajmniej nie jest pewne), niektóre sprawy mogłyby być rozpoznawane w języku polskim. W oddziale centralnym (a więc zawsze języku obcym) podmioty polskie musiałyby bronić swoich patentów przed próbami ich unieważnienia.

Powodem krytyki porozumienia JSP jest też fakt, że nie zawiera ono ani rozwiązań należycie chroniących przed nadużywaniem patentów i wykorzystywaniem ich do celów antykonkurencyjnych, ani chroniacych pozycję podmiotów, wobec których wysuwane są zarzuty (chodzi np. o ochronę tajemnic produkcyjnych i handlowych czy zagwarantowanie prawa do wysłuchania przez są).

Rozwiązania mające obowiązywać w ramach pakietu patentowego są bardzo kosztowne i rodzą poważne ryzyka prawne i gospodarcze oraz liczne, często niewymierne obciążenia wynikające z blokowania rozwoju i innowacji. Sa one nieadekwatne z punktu widzenia potrzeb małych i średnich przedsiębiorstw, lecz są podporządkowane interesom silnych użytkowników systemu patentowego, prowadzących spory transgraniczne o dużym zasięgu terytorialnym.

prof. dr hab. Aurelia Nowicka

Uniwersytet im. Adama Mickiewicza w Poznaniu

aunow@amu.edu.pl

${ }^{36}$ Zob. art. 18 ust. 2 akapit drugi rozporządzenia nr 1257/12. Szerzej na ten temat A. Nowicka, Patent europejski o jednolitym skutku..., s. 22-23. 


\section{A UNIFIED PATENT COURT - FROM POLAND’S PERSPECTIVE}

Sum mary

The purpose of this paper is to analyse selected legal issues that arise from the Agreement on a Unified Patent Court and, in particular, the questions which emerge when it comes to the legal status of that Court in light of the European Union law, or doubts regarding the compatibility of the UPC Agreement with the Constitution of the Republic of Poland.

First, the content of the UPC Agreement and the conditions precedent to its entry into force are presented. After that, the status of the UPC is analysed against the background of its provisions describing the Unified Patent Court as a 'court common to the Contracting Member States' and 'part of their judicial system.' The analysis refers to opinion 1/09 of the Court of Justice of 8 March 2011 on the previously envisaged agreement aimed to constitute a European and European Union Patents Court.

The question of permissibility, or rather constitutionality, of vesting the competences of the national judiciary to the jurisdiction of the UPC has been raised, together with a number of other reservations concerning the compability of the UCP Agreement with Poland's constitutional order and contained in it standards of fundamental rights protection, such as the right to a fair trial (i.e. in the context of the language of proceedings before the UPC). 
Copyright of Journal of Law, Economics and Sociology is the property of Faculty of Law and Administration of Adam Mickiewicz University in Poznan and its content may not be copied or emailed to multiple sites or posted to a listserv without the copyright holder's express written permission. However, users may print, download, or email articles for individual use.

Właścicielem praw autorskich do „Ruchu Prawniczego, Ekonomicznego i Socjologicznego” jest Wydział Prawa i Administracji Uniwersytetu im. Adama Mickiewicza w Poznaniu. Zawartość czasopisma nie może być kopiowana, przesyłana do innych stron internetowych bądź zamieszczana na blogach bez pisemnej zgody wydawcy. Niemniej artykuły można drukować, kopiować lub przesyłać w formie elektronicznej na własny użytek. 